\title{
Thematic Interior at the Indischetafel Café As a Media for Forming Bandung Tempo Dulu's Athmosphere
}

\author{
Tiara Isfiaty, Tri Widianti Natalia \\ Universitas Komputer Indonesia \\ Jalan Dipati Ukur 112 - 116 Bandung 40132
}

\begin{abstract}
The interior elements designed in a specific theme are aimed to shape a character, a perception, and an atmosphere of spaces. In Bandung, culinary facilities that carry the theme of the old-style interior design of the Dutch East Indies are quite popular. This study aims to contribute guidance in creating the quality of space by applying the selection of decoration and furniture elements (moveable interior elements) and the arrangement of walls, floors, and ceilings (unmoveable interior elements). This study applies a case study as a research method and a direct observation of the Indischetafel Café, while the analysis uses a descriptive analysis method. This study is to examine aspects of interior element arrangement in the Indischetafel Café in bringing the atmosphere of Bandung Tempo Dulu.
\end{abstract}

Keywords: thematic interior, interior elements, space atmosphere, Bandung Tempo Dulu

\section{INTRODUCTION}

Space atmosphere is an important element of culinary facilities that influence the buying decision process of visitors. The visitors not only respond to goods and services offered but also to the environmental atmosphere created there. Indischetafel Café is one of the culinary facilities in the form of a family restaurant that applies space atmosphere of Bandung tempo dulu (the IndoDutch). This café is located in the old town area, near Braga area. According to Bandung Digambar Euy (2006: 17), Braga, historically, is recorded as an elite gathering area of certain European people since 1879. This is also the main reason for the selection of culinary facilities in theme Bandung tempo $d u l u$ as a case of study.

According to Pile, (in Isfiaty, 2015: 392), space contains architectural elements of the structure and the forming of its space in the form of columns, walls, floors, and roof. It also contains interior elements in the form of space equipment, namely furniture and enrichment (accessories) of space. Someone has a certain psychological response to space. Various psychological components involving vision are called visual systems. The human visual system allows one to absorb information from its environment. In the context of interior space, this condition is a form of space interaction with humans as a space user. The interaction causes the emotional release of the space user to space itself. This means that space must have an influence on the psychological condition of the human being who remains in it. Adler (1968) in Sally (2009: 5) states that:

"When you are creating spaces that one or few people will use, the dominant sense of those user should be recognized. Dominant sense help determine what information from physical world makes it way into their psychological world, and what influence it has once arrived." 
The interaction, as mentioned above, creates a sense of place in the experience of space atmosphere about Bandung tempo dulu. Visual interaction will not occur without material character or expression of interior elements. The quality of a space becomes a success factor in shaping the sense of place of its users. The intensity of a space quality is directly related to the selection of the type and arrangement of its interior elements. Structuring the interior elements of culinary facilities becomes important since it is first seen, assessed, and will be remembered by visitors.

The scope of this study raises the objectivity of the sense of place. This is related to human interaction with the environment, especially the environment/interior through architectural and interior elements. The purpose of this study describes the objective sense of place experienced by the user related to his interaction with space which refers to the ten elements of space quality (D.K. Ching, 1996: 56), namely: (1) Feeling, mood or atmosphere, these elements refer to the human psychological atmosphere such as affection, excited feeling and visitor happiness; (2) Image and style, these elements refer to the implementation of thematic interior design; (3) Level of space closure, this element refers to the architectural elements as well as elements of space; (4) Comfort and security, these elements refer to the availability of support facilities and management or service systems; (5) Light quality, this element refers to the implementation of thematic interior implementation; (6) Focus and space orientation, these elements refer to the implementation of thematic interior design; (7) The color and pattern, these elements refer to the implementation of thematic interior design; (8) Acoustic properties of the environment, this element refers to the environmental conditions; (9) Environment of air temperature, this element refers to the existing environmental conditions and the condition of the environment built at once;
(10) Flexibility, this element refers to the architectural attachment elements to the space elements or vice versa.

\section{METHOD}

This study uses a case study as it relates to the character of a typical subject in the case of space experience formation. For the discussion, it is used descriptive analysis. Following Mohamad Ali (1985: 131), the descriptive method is appropriate in this study because it seeks to solve and answer the problems faced in the current situation. Meanwhile the analysis refers to Miles and Hubermen in Rohidi (2011: 233), which describes the three main flows in the analysis including data reduction, data presentation, and conclusion. In this study, the research subjects are individuals who have interest and habit to visit thematic culinary facilities in Bandung. The research location is Indschtafel Café located in Jl. Sumatra No.19 Bandung. Data collection techniques conducted in this study are (1) field study, in carrying the field study, researchers obtain data collection through observation, questionnaires, and documentation; (2) observation is made both on the moveable interior elements and un-moveable interior elements in the café as the case study. Observations are done to get the information about the café operational hours, the peak hours, and to observe the activities occurred in the café; (3) questionnaire, the determination of respondents for questionnaires in this study refers to the accidental technique as stated by Sarini (2015: 26), that is the technique of determining respondents accidentally by the decision of the researcher if the candidate is considered suitable as a source of data.

\section{RESULTS AND DISCUSSION}

The results of the field study on the interior elements of Indischetafel Café can be analyzed as follows: 


\section{a. Documentation}

Indischetafel Café is a family restaurant owned located in the old town area, adjacent to the Bancey region, which has been known since the 1870s and Braga. Historically, the Braga region was known as an elite area of European people gathering since 1879. Indischetafel Café's public room begins with a terrace, then a lobby and the dining area. The terrace is functioned as a dining area for smokers because it is open area and has directly an access to the outside of the building. The lobby is a room that has an open access directly to the terrace. In the lobby, there is a cashier area and a place of display for pastry. The dining area inside the building is divided into four rooms. Three medium-dimensional rooms and one large-dimensional room are used for the dining area. This is an adaptation to the initial function of the building as a residential facility.

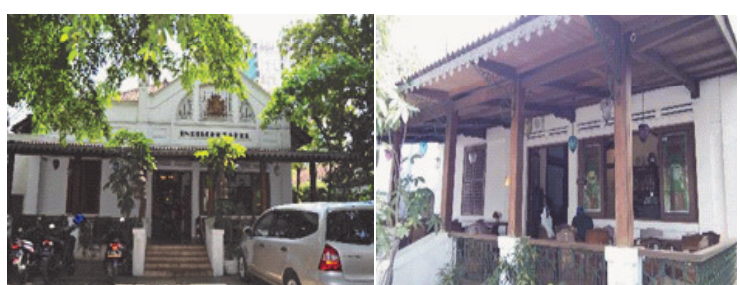

Pic 1. Façade architectur of the Indischetafel Café Source: writer's documentation, 2016

The presence of the antique object display, as the result of the owner hunting, shows the Indischetafel Cafés characters as well as shows the identity of Bandung tempo dulu. Those characters differs the Indischetafel Café from others. The diversity and uniqueness of the display object as its interior elements, such as antique bicycles, accordion, gramophone and antique camera are reflected in the Indischetafel Café's motto "Achter elk stukje schuilt een eigen verhaal," which means every detail has a story. The following is the documentation of the Indischetafel Café's lobby that completed with the details of the object display to bring up the theme of Bandung tempo dulu. On the right side, there is the cashier area. Next to the counter, there is a showcase for pastry. In the central room, there is a table to display a jar containing cookies, with a display cabinet containing special snack of Bandung as the background. The antique cash register is one of the icons in the lobby area which is very relevant to the theme of Bandung tempo dulu because of its European nuances. The cash register was discovered in 1819. It operates without the electricity. Another icon in this area is a plectocyle or tricycle which very 1819's European nuances, the year in which the object was for the first time patented in England as Denis Johnson's creation. The floor area of the lobby is the motif tiles with green circular pattern surrounding border. The walls have wooden-framed window openings, with stained glass. The ceiling has a height of about four meters. On the ceiling of the lobby area, there are decorative lamps with the selection of yellow lights.
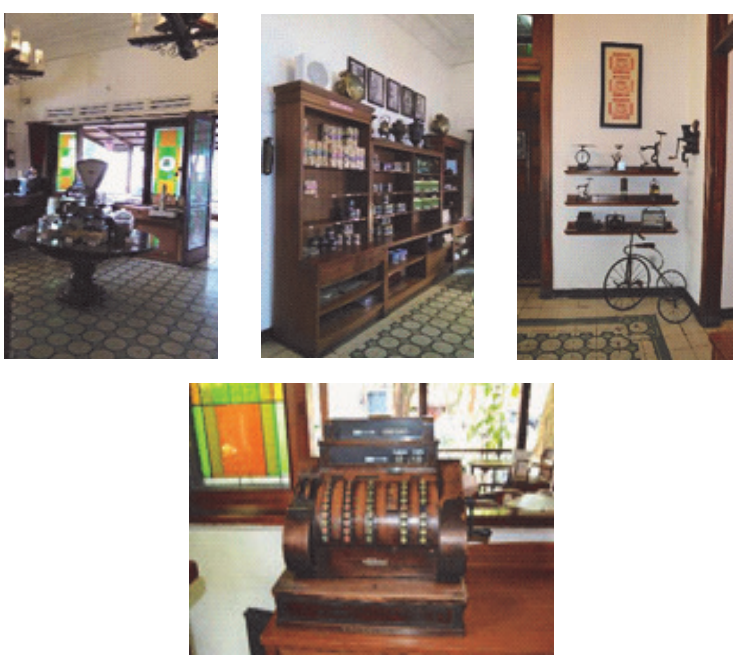

Pic 2. Lobby area of the Indischetafel Café with the antique cash register and plectocyle, which are the icons of the lobby Source: writer's documentation, 2016

The following is the documentation of the dining area and its display details. Due to the initial function of the building as residential facilities, the dining area is divided into four parts. There is a hallway leading 
to the dining area 4 that has a large dimension. On the right and left side of the alley, there is an access to three other dining areas. The dining area 1 is located on the right side of the corridor from the lobby, which is a window opening with double shutters. The wood-framed wooden shutters have clear glass and wooden window shutters. The floor is a hexagon-shaped tile with a dark gray. The ceiling has a height of about four meters. There are decorative lamps on the ceiling with yellow lights.
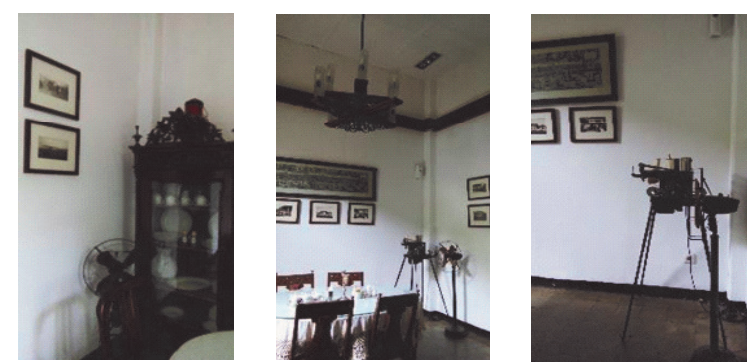

Pic 3. The dining area $1 \&$ the display object of the antique sewing tools as the enrichment of space.

Source: writer's documentation, 2016

The dining area 2 that located opposite to the dining area 1 has a direct access without doors to the dining area 3 . The dining area 2 has a window opening with the double shutters. The double window shutters have the wooden frames with clear glass and wooden window shutters. The window in the dining area 2 does not function as an opening tool. The old nuance in this room is dominated by furniture of the antique cabinets, chairs, antique swivel chair, shaving table, and side table. Its floors are gray hexagonal shaped tile. The ceiling has a height of about four meters. There is a decoration lamp on the ceiling with yellow light.

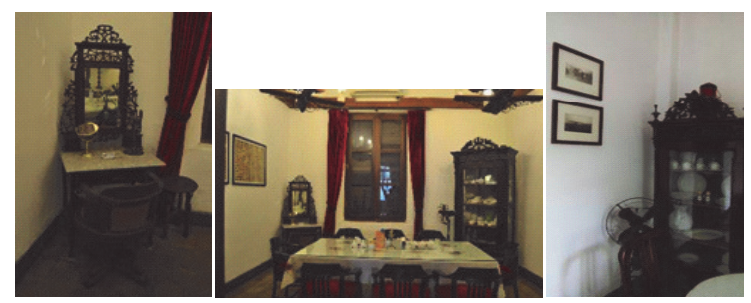

Pic 4 . The dining area 2 with the antique cabinet, chair, antique swivel chair, shaving table as the room icon of the Café Source: writer's documentation, 2016
The dining area 3 contains two dining tables. It has indoor access to the dining area 4. The dining area 3 has a double shutter window. Framed wooden window shutters with clear glass and wooden leaf window. The window shutters have wooden frames with clear glass and wooden window. The window in the dining area 3 is not functioned as an opening. The floor is gray-hexagonal shaped tile. The ceiling has a height of about four meters. There are decorative lamps on the ceiling with yellow lights. Portable camera obscura and gramophone become the icons of the past in this area. Gramophone is a music player from Europe produced around 1918. In this space, the object is placed on an eight-pointed white marble table as a tabletop.
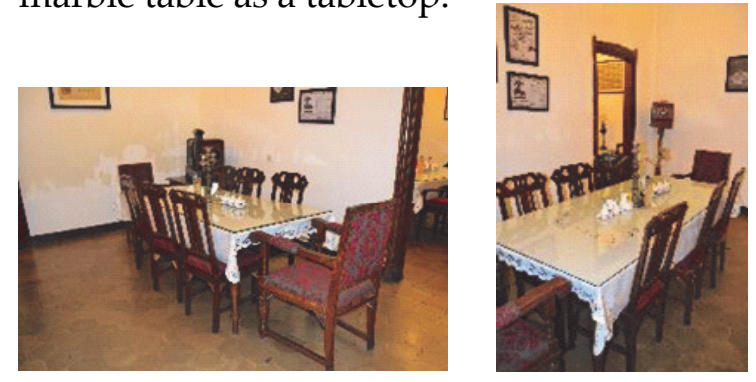

Pic 5. The dining area 3 of the Indischetafel Café Source: writer's documentation, 2016
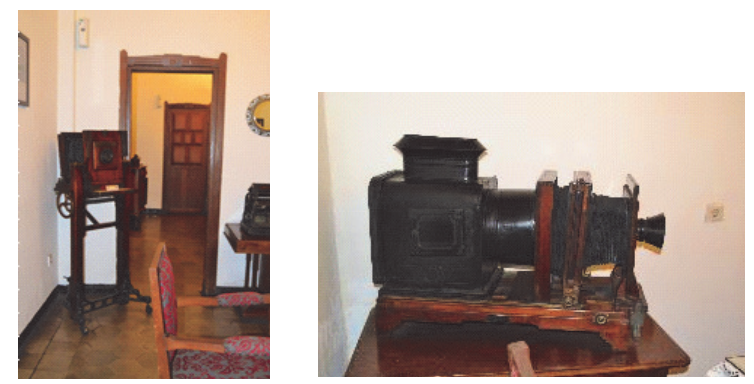

Pic 6. The portable camera obscura as the icon of the dining area 3.

Source: writer's documentation, 2016
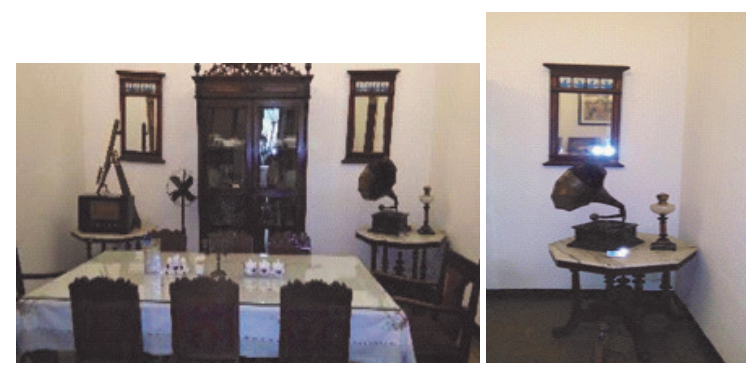

Pic 7. A gramophone and antique binoculars as the icon in the dining area 3.

Source: writer's documentation, 2016 
A large dimension of the dining area 4 has a wooden framed window with stained glass similar to the lobby area. An accordion piano is one of the icons in this dining area. The accordion and casing are placed on the crate that functioned as a table. The accordion piano is one of four types of a gramophone. European nuance arises because the instrument which was created by C.F.L. Buschmann, in 1822, comes from Berlin, Germany. The floor of the room is tile motif of four dark red petals with borders surrounding it. In the four dining areas, their ceilings have a height of about four meters. There are decorative lamps on the ceilings with yellow lights.
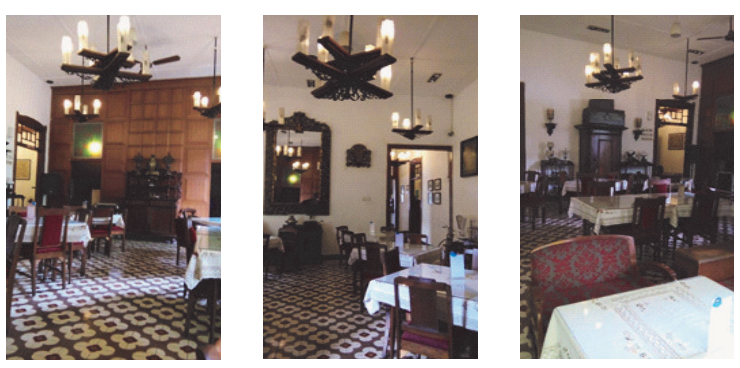

Pic 8. The pictures show the dining area 4 . Source: writer's documentation, 2016
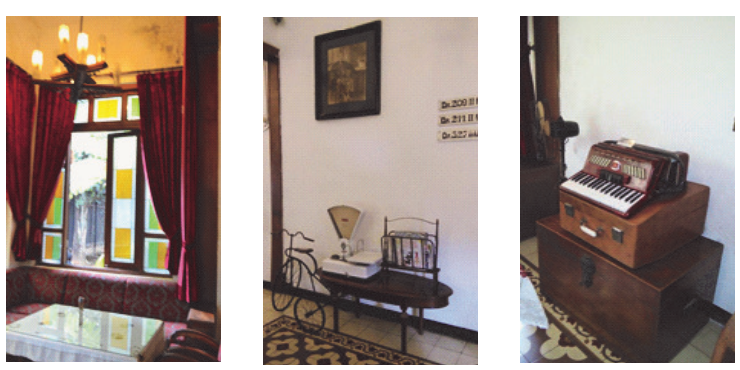

Pic 9. The details of the stained glass windows and display objects of bicycles, scales, and accordion piano instruments.

Source: writer's documentation, 2016

\section{b. Questionnaire}

Analysis of the role of the thematic interiors at the Indischtafel Café in the formation of Bandung tempo dulu atmosphere is based on the input of respondents towards the seven categories of room quality forming elements, i.e. the atmosphere - the image and the style - the level of space closure - comfort and security - light quality - focus and space orientation - flexibility. Each category has its own problems. Following are the questionnaire data input and description of the sense of place experienced by the Indischetafel Café's respondents related to their interaction with space based on ten elements of space quality:

$260 \%$ respondents answered agree that the architecture of the café reminds them of the past mood, 33\% respondents answered strongly agree, and $7 \%$ respondents thought neutral about it.

B Image and Style

$146 \%$ respondents answered agree that the interior elements (floors, walls, and ceiling) are influential in giving the impression of the past, 54\% respondents strongly agreed about it.

$253 \%$ respondents agreed that the furniture design (chairs, tables, tables, tables) had an effect on giving the impression of the past, $47 \%$ respondents strongly agree with it.

$360 \%$ respondents answered agree that the elements of the decoration (photos, lamp designs, and the aesthetic elements) had an effect on giving the impression of the past, $40 \%$ respondents strongly agree on it.

C Level of Closing Space

$167 \%$ respondents agreed that the number and design of windows and doors bring the atmosphere of the past, $20 \%$ respondents neutral, and $13 \%$ of respondents strongly agreed with it.

$253 \%$ respondents answered agree that the proportion of ceiling height to the room area reminds them of the past mood, $27 \%$ respondents answered strongly agree, and $20 \%$ respondents answered neutral about it.

\begin{tabular}{|c|c|}
\hline $\mathrm{D}$ & Comfort and Security \\
\hline 1 & $\begin{array}{l}40 \% \text { respondents answered agree that the } \\
\text { Indischetafel Café provides a spacious and } \\
\text { comfortable parking area, } 33 \% \text { respondents } \\
\text { answered neutral, } 13 \% \text { respondents an- } \\
\text { swered disagree, and } 14 \% \text { respondents an- } \\
\text { swered strongly agree with it. }\end{array}$ \\
\hline 2 & $\begin{array}{l}53 \% \text { respondents agreed that they were com- } \\
\text { fortable with the type of ingredients/menus } \\
\text { sold in Indischetafel Café. This is an identical } \\
\text { feature of past time food/drink, } 27 \% \text { respon- } \\
\text { dents strongly agreed, and } 20 \% \text { respondents } \\
\text { answered neutral to it. }\end{array}$ \\
\hline
\end{tabular}


$347 \%$ respondents answered agree that they were comfortable with the air that relies on the high ceilings without air conditioning, $53 \%$ respondents strongly agreed.

$4 \quad 73 \%$ respondents answered agree that they are comfortable with the service, which is typical of the café, $20 \%$ respondents answered neutral, and $7 \%$ respondents answered strongly agree on it.

E Light Quality

$166 \%$ respondents agreed that the interior space lighting supporting the past atmosphere, 30\% respondents strongly agreed, and $4 \%$ respondents disagreed with it.

$260 \%$ respondents agreed that the colors applied inside and outside of the café supported the past atmosphere, 33\% respondents strongly agreed, and 7\% respondents answered neutral about it.

F Space Focus and Orientation

$160 \%$ respondents agreed that the scent produced by the Indischetafel Café was the first thing to support the atmosphere of the past when they entered the shop/café, 26\% respondents said neutral, and $14 \%$ respondents strongly agreed about it.

$260 \%$ respondents answered agree those interior materials (floors, walls, ceilings) was the first thing to give an impression when they entered the cafe, $40 \%$ respondents answered strongly agreed.

$360 \%$ respondents agreed that the counter, serving table, and the waitress, were very easy to be found, $20 \%$ respondents answered strongly agree, and 20\% respondents answered neutral about it.

$466 \%$ respondents answered agree that the architecture of the café was the first time to support the atmosphere of the past when they came and entered the café, $34 \%$ respondents answered strongly agree to it.

\begin{tabular}{ll}
\hline $\mathrm{G}$ & Flexibility \\
\hline 1 & $\begin{array}{l}40 \% \text { respondents answered agree that the ar- } \\
\text { chitecture and the interior design of the café }\end{array}$ \\
& were suitable for similar facilities with dif- \\
ferent themes (modern), 33\% of respondents \\
answered neutral, 20\% respondents agreed, \\
and 7\% respondents strongly agreed.
\end{tabular}

Table 1. The table sense of place respondent of the Indischetafel Café Source: Author, 2016

Following are the descriptive analysis of the perceptions of respondents or the sense of place of the Indischetafel Café, which refer to percentage of the answers of strongly agree and agree:

A. Experiences on the quality of space for respondents related to the atmosphere in the café are started from interior factor followed by architectural exterior factor.

B. Experiences of room quality for the café respondents related to the image and style, interior elements, furniture elements, and the decoration elements are the dominant factors that affect the formation of the past nuance. For the sake of objectivity, the sequence of the three elements is sorted based on the strongly agreed response of the respondents. The sequence is the element of interior according to the respondents becomes the most influence on the atmosphere of Bandung tempo dulu, followed by the furniture element and the last, decorating element.

C. Experiences on the space quality of the respondents related to the level of the space closure and the proportion of space in the café are the dominant factor that affects the formation of the past atmosphere, followed by the design of openings such as doors and windows.

D. Experiences of the room quality of the respondents related to the comfort and safety and natural caring are the dominant factor affecting the comfort and security in the café room, after that, the good service included management, behavior and visual (uniform) places the second factor; the menu becomes the third factor. Exterior factors, especially the ease of parking facilities, are the minor factors that affect the comfort and security of the café.

E. Experiences of the space quality related to the quality of light and the light system are a dominant factor influencing the formation of the atmosphere of the past than the color applied inside and outside the room.

F. Experiences of the room quality related to the focus and orientation of space, room materials (floor, wall, and ceiling) are 
the matters of concern, and influence on the formation of the past nuance. After that, the architectural design factor, layout and organization space, and finally, the scent factor.

G. Experiences of the room quality related to the flexibility, architecture, and the interior of the café are two things that cannot be separated, and it is impossible to apply other design themes in addition to the Bandung tempo dulu.

\section{CONCLUSION}

Human interaction in a room must be conditioned. The condition can be formed based on both the internal and external factors. The Interior and architectural elements are the internal factors, while the environment (good and bad smellings), service management, and stimulation from researchers with questionnaires, are the external factors. The cooperation of those two factors becomes media in raising the sense of the place objective. Based on this research, the architectural elements of the Indischetafel Cafes are the supporting elements that shape the initial perception of humans in the atmosphere of space within them. While the interior elements of the Indischetafel Café, such as audio, visual, management, and smells are the main elements. This is in harmony with a very good room quality of the Indischetafel Café. Its space quality refers to the element of flexibility, in which respondent judge not to allow the application of other design themes except the theme of Bandung tempo dulu. There are two architectural elements that play a role to shape the visitor's perception of Bandung tempo dulu. First is the space of the opening factor, and second is the space of ceiling proportion. The interior elements that have a role to shape the visitor's perception of the atmosphere Bandung tempo dulu, based on the answers of the respondents, can be sorted as follows: 91) the technical air conditioning in the room; (2) the use of the flooring materials, walls, and ceilings; (3) the selection and interior color harmonization elements; (4) the technical room lighting; and (5) the layout of furniture and organization space.

\section{Bibliography}

Alifia Wida Izzati, Yuni Maharani, Dudy Wiyancoko

2017 “Relasi Desain dan Tata Letak Sarana Duduk Terhadap Kenyamanan Pengunjung Kafe" dalam Jurnal Desain Interior Vol. 2 No.1 ISSN: 25272853 eISSN: 2549-2985 DOI: http:// dx.doi.org/10.12962/j12345678.v2i1. 2379

Anonim

2006 Bandung Digambar Euy - Sejarah Singkat Bandung Dalam 100 Sketsa Full Colour. Bandung: Art Paper Publishing House.

Augustin, Shally

2009 Place Advantage: Applied Psychology for Interior Architecture. Hoboken, New Jersey: John Wiley\&Sons, Inc.

D.K Ching, Francis

1996 Ilustrasi Desain Interior. Jakarta: Penerbit Erlangga.

Mohamad Ali

2013 Penelitian Kependidikan Prosedur $\mathcal{E}$ Strategi. Bandung: Penerbit Angkasa.

Sarina Abdullah, Taufik Edy Sutanto

2015 Statistika Tanpa Stress. Jakarta: Penerbit Transmedia.

SP Honggowidjaja

2005 “Menyikapi Kolom dalam Ruang Selaku Elemen Struktural Maupun Artifisial" dalam Jurnal Dimensi Interior Vol. 2 No. 2 pp. 109-120 ISSN: 1692-3532 
Tiara Isfiaty

2015 “Kreativitas Desain Berbasis Karakter Lokal Sebagai Pembentuk Pengalaman Ruang pada Fasilitas Komersial" dalam proceeding Paramadina Research Day 2015 ISSN 2303-1301, Jakarta : Penerbit Universitas Paramadina
Tjetjep Rohendi Rohidi

2011 Metodologi Penelitian Seni. Semarang: Penerbit Cipta Prima Nusantara Semarang CV. 